\title{
Trends and Challenges in Improved Agricultural Inputs Use by Smallholder Farmers in Ethiopia: A Review
}

\author{
Mideksa Fufa Jilito ${ }^{1, a, *}$, Desalegn Yadeta Wedajo ${ }^{1, b}$ \\ ${ }^{I}$ Department of Rural Development and Agricultural Extension, College of Agriculture and Environmental Sciences, Haramaya \\ University, P. O. Box 138, Dire Dawa, Ethiopia
}

*Corresponding author

A R T I C L E I N F O A B S T R A C T

Review Article

Much of the sustained agricultural growth necessary for poverty reduction and sustainable development comes from adequate and expanded improved agricultural inputs use like hybrid seeds, pesticides, insecticides, herbicides, fungicides, and inorganic fertilizer. However, smallholder farmers faced various and empirically unidentified constraints in the sustainable use of

Received : 03/10/2019

Accepted : 26/06/2020 improved agricultural inputs. This study, therefore, is to examine the trends and challenges farmers faced to use improved inputs. The study has used secondary data from various databases such as FAOSTAT, World Bank, Ethiopian Institute of Agricultural Research and agricultural statistics. Simple graphical sketch, tabular and percentage analysis was employed for interpretation of the data. The study revealed that the trends in the use of various improved inputs are not based on the regular basis. The sustainable improved input intensification by smallholder farmers was influenced by various socio-economic, physical, and institutional factors. Understanding trends and challenges in input utilization provide baseline information for input intensification policies and strategies. Therefore, this review pointed out that it is possible to increase inputs intensification by smallholder

Keywords:

Improved agricultural input Smallholder

Trends

Ethiopia farmers.

\section{Introduction}

In September 2015, the United Nations adopted the 2030 Agenda for Sustainable Development, which includes 17 Sustainable Development Goals (SDGs) to guide policy towards sustainability. The goals are to be implemented and achieved in every country from the year 2016 to 2030. Amongst others, this study covers the aspects of end hunger; achieve food and nutrition security through sustainable agriculture. Sustainable improved input use is a core factor in achieving many of the SDGs (Delzeit et al., 2018). However, low application of improved inputs results in the low output (Ayele and Bosire, 2011). Despite the fact that poverty-reducing agricultural growth and sustainable development goals achievement in Ethiopia is expected to come largely from expanded use of improved inputs, farmers use few improved agricultural inputs (Sheahan and Barrett, 2014).

The expansion in the use of improved agricultural inputs is most important for improving agricultural productivity (Venkatesh and Nithyashree, 2014). Much of the sustained agricultural growth necessary for poverty reduction and sustainable development comes from adequate and expanded improved agricultural inputs use like hybrid seeds, pesticides, insecticides, herbicides, fungicides, and inorganic fertilizer (Ajah and Nmadu, 2012; World Bank, 2013). According to Mellor (2014), growth in production and income generated from an enhanced application of improved inputs. Therefore, tremendous increases in agricultural productivity in a relatively short period time takes place through widespread uptake of yield-enhancing improved agricultural inputs (Ayele and Bosire, 2011; Sheahan and Barrett, 2017).

In Ethiopia, the focus has been given on smallholder intensification through using improved agricultural inputs particularly seed varieties and inorganic fertilizer. Despite this, improved agricultural input use in Ethiopia is still lower than that of many other countries. For example, the average application rates of fertilizer for arable crops are estimated to 14 kilograms per hectare in Ethiopia in 2016 compared with average application rates of $30 \mathrm{~kg} \mathrm{ha}^{-1} \mathrm{year}^{-1}$ in Kenya in 2006 (Smaling et al., 2006) and $102 \mathrm{~kg} \mathrm{ha}^{-1}$ 
year $^{-1}$ in Asia in 1995 (Hazell, 2009). Hence, empirical evidence confirms that the trend in the use of inorganic fertilizer in Ethiopia is low and by far less than the world average of $100 \mathrm{~kg} \mathrm{ha}^{-1}$ year $^{-1}$ (Smaling et al., 2006). Moreover, according to Living Standard Measurement Study-Integrated Surveys on Agriculture (LSMS-ISA) data, $55.5 \%$ of cultivating households use inorganic fertilizer in Ethiopia. Agro-chemical use statistics taken from the LSMS-ISA (Ethiopia 2011/2012) household survey data indicate that agrochemicals are used by $30.5 \%$ of household cultivators (Sheahan and Barrett, 2017). The statistics relate only to chemicals applied to crops on the field, not those used in storage.

From 1995 to 2014, the average yields of maize for all African countries increased from 1.69 ton $\mathrm{ha}^{-1}$ to 2.1 ton $\mathrm{ha}^{-1}$, that is a $25 \%$ growth over the 20 years. Other crops have also been performing relatively well. However, the yield growth rates are far below levels in other regions. Over the same period, maize yield grew by more than $70 \%$ in Asia and $150 \%$ in South America. Hence, to accelerate agricultural productivity growth in Ethiopia, a paradigm shift in utilizing improved agricultural inputs in sustainably manner is crucial (Alia, 2017). However, recent evidence shows that Ethiopian farmers underutilize these inputs particularly on strategic staple crops such as maize and sorghum (Sheahan and Barrett, 2017). Thus, sustainable agricultural growth in Ethiopia that increase productivity depends on sustainable improved inputs intensification and utilization.

Agricultural input intensification holds the potential of transforming Ethiopian agriculture in order to propel economic growth (Chirwa and Dorward, 2013). Agricultural production and productivity growth in Ethiopia are improving but remains too slow. Thus, this study focused on sustainable use of improved inputs that will rapidly increase agricultural yield. While myriad studies look at some facet of improved input use throughout the country, no studies, to our knowledge, focus specifically on recent trends of farmer input use or on challenges farmers faced in improved inputs use. A major and fundamental gap remains to analyse trends of current input utilization at the country level. This study, therefore, aimed to fill this gap using newly available data from various sources such as FAOSTAT.

The earlier review of literatures focuses on the role of agricultural inputs in agricultural growth. It also focuses on the amount of improved inputs utilized. The results of the few studies that have been carried out in Ethiopia have been conflicting. Therefore, there is a gap in the literature as far as a study on the trends of improved agricultural inputs used since 1996 in Ethiopia. For this, the pursuit of sustainable input intensification strategies necessitates conducting this study. Thus, this study sought to fill this research gap by answering the following questions: (a) how can the trends of inputs use give direction for sustainable improved agricultural inputs intensification? (b) What are the social, economic, and institutional constraints of sustainable improved inputs intensification and utilization?

Empirical Review on Challenges Smallholder Farmers' Faced in Utilizing Inputs

The low utilization of improved agricultural inputs in Ethiopia is due to confluence constraints. These include physical, resource, socio-economic, and institutional constraints (Diagne et al., 2013). Physical constraints relate to the physical availability of improved inputs to farmers (Chianu et al., 2012). Even when these inputs are imported, poor infrastructure pushes up transaction costs which make their distribution to production zones difficult. Economic barriers concern the affordability of inputs to resource-poor farmers. The widespread and high poverty combined with incomplete credit and an input market implies that smallholder farmers have limited resources to invest in productive inputs (Druilhe and Barreiro-Hurle, 2012). Therefore, empirically analysing and addressing these challenges holds enormous potential for boosting and sustaining yield growth of crops, food security and poverty reduction.

\section{Limited and Late Delivery of Seed}

Seed is a key input for improving crop production and productivity in Ethiopia. For instance, Li et al. (2010) found that $30 \%$ of the growth rate of agricultural production was due to new seed varieties. Despite the release of several crop varieties, there has been limited use of improved seeds by the majority of Ethiopian farmers. Only $2.9 \%$ of the farmers in Ethiopia reported using the improved seed in 2011 (CSA, 2011). Among others, the unavailability of quality seeds at the right place and time is one of the key factors accounting for limited use of improved crop seeds, which further contributing to low agricultural productivity. Delivering improved seeds available in research centers to the hands of farmers is challenging issues with potential barriers. A key factor has been inadequate improved seed varieties that satisfy the needs of farmers and markets. Another challenge is weak quality control systems of seed, leading to a proliferation of fake seed which is hurting farmers (Gerstenmier, 2015).

\section{Limited and Untimely Supply of Fertilizers}

Ethiopian smallholder farmers use lower fertilizer application rates compared with other countries due to the shortage of supply, late arrival and high price. Until 2013, urea and DAP (di-ammonium phosphate) fertilizers have been only fertilizer sources that have been in use in the country. None of these are locally produced and supplied by imports to meet the demand. Delivery systems have not performed well, which has caused delays in the procurement and distribution (Salami et al., 2010). This is exacerbated by poor port facilities and high transport costs (Gerstenmier, 2015). These affect the availability, accessibility and affordability of fertilizer use in rural areas. The rural area is underserved with the functioning of agro-dealers because they concentrate in cities and other big towns that are far away from the farmers, hence making fertilizers inaccessible to farmers (Sheahan et al., 2013).

\section{Weak Linkages of Research-Extension-Farmers}

The usefulness of the linkages of research-extensionfarmers and related information services rests on both the farmer's access to the source of the information and its quality and appropriateness. However, according to Belay and Alemu (2017), empirical studies indicated the presence of weak links between research and extension as the major factor limiting the flow of information, knowledge, use of new technologies, and resources among actors in the 
technology-delivery utilization system and recommend measures to overcome the widely acknowledged weaknesses. In Ethiopia the focus has been on smallholder intensification through access to improved inputs. Despite various attempts to strengthen them, the linkages between research and extension were weak, and collaboration between public and private partners limited (Salami et al., 2010).

Weak Linkages Among Agricultural Inputs Providers

Ethiopia's agricultural extension services are characterized by a multiplicity of actors include public extension sector, private extension providers, nongovernmental organizations and agro-chemical companies. Linkages between these actors are weak and each actor is driven by its own motives and interest. For instance, research centres managed under the Ministry of Agriculture release different improved crop varieties which recognize different agro-ecological conditions. However, extension officers/development agents who are close to farmers and organized under Ministry of Agriculture, NGO and other private extension providers have no or limited linkage with research centres to scale up released technologies. Moreover, a review of the relevant literature shows that public extension services do not reach the bulk of the smallholder farmers due to a shortage of extension professionals, inadequate operational funds, topdown planning and implementation methods, centralized management, and weak accountability systems (Gebremedhin et al., 2012).

\section{Poorer Physical Infrastructure}

According to Rashid et al. (2013), poor infrastructures impede agricultural activities in Ethiopia. The key challenges are poor conditions of the transportation systems particularly poor design and maintenance of the road. The road system, which is the most important for market development in terms of the distribution of inputs to farmers, is the most serious infrastructural bottleneck facing agricultural development. Road conditions are poor especially in the rainy season. This makes the flow of inputs to rural areas difficult and expensive (Gerstenmier, 2015). As a result of the poor road network, smallholder farmers depend on inefficient forms of transportation including the use of animals (Salami et al., 2010). These infrastructural factors, thus, play an important role in supporting inputs supply and distribution (Gebrehiwot and van der Veen, 2014).

\footnotetext{
Limited Use of Information Communication Technologies (ICTs) Applications to Supplement Extension Services

ICTs include the use of computers, internet, geographical information systems, smart mobile phones as well as traditional media such as community radio or TV. These have the potential to increase farm productivity by enhancing ease access to agricultural inputs. However, the use of ICTs in Ethiopia is low (World Bank, 2013). Only Agricultural Transformation Agency has created in 2013 a new information hotline that gives smallholder farmers across the country access to agricultural information services through calling 8028 freely.
}

\section{Less Irrigation Facilities/Rain-Fed Dependent}

Although irrigation facilities are important to address variable and deficient rainfall, almost all of smallholder agriculture in Ethiopia is rain-fed. Research on the staple teff grain showed a three-fold yield increase when using irrigated field compared with rain-fed ones and the crop yield significantly dropped when it experienced seasonal water stress (Yihun et al., 2013). A study conducted in an agro-pastoral area of the Somali Region found that high levels of poverty are related to a lack of access to irrigation (Muktar et al., 2014).

\section{Low Purchasing Power of the Farmers}

There is a strong concern that the inputs needed to increase productivity are financially unaffordable to many poor farmers of the country (Wiggins and Brooks, 2010). For various reasons, banks or small and medium enterprises in Ethiopia are reluctant to lend to smallholder farmers. Consequently, rural households in Ethiopia are still largely reliant, for their financial needs, on informal providers. This limits sustainable input intensification for smallholder farmers (Gerstenmier, 2015).

\section{Material and Method}

The study has used secondary data from various databases. The data on the use of improved agricultural inputs such as pesticides, herbicides, insecticides, and fungicides were compiled from FAOSTAT. Moreover, data on the yield of major cereal crops and fertilizer use by nutrient (Nitrogen and Phosphate) was compiled from FAOSTAT. The information on the fertilizer application rate was collected from World Bank. In addition, data on released improved crop varieties obtained from Ethiopian Institute of Agricultural Research. Agricultural Statistics at a glance and Agricultural Growth Programme baseline survey also used as a data source. Then a synthetic review was undertaken using an in-depth review of past trends from related literature such as journal articles, books, conference proceedings, research reports, master thesis and $\mathrm{PhD}$ dissertations and other publications from government and non-government organizations. The arguments of different researchers were taken and the authors support accordingly and made an interpretation. Simple graphical sketch, tabular and percentage analysis was employed for interpretation of the data.

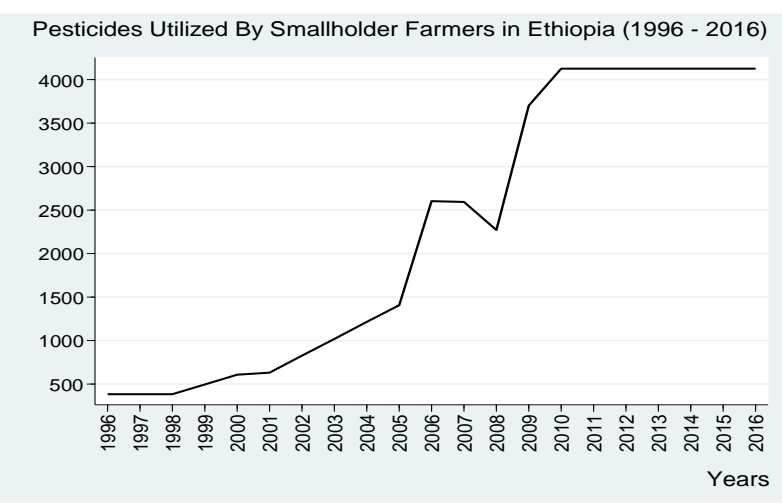

Figure 1. Pesticides utilized in tons (Source. FAOSTAT, 2019) 


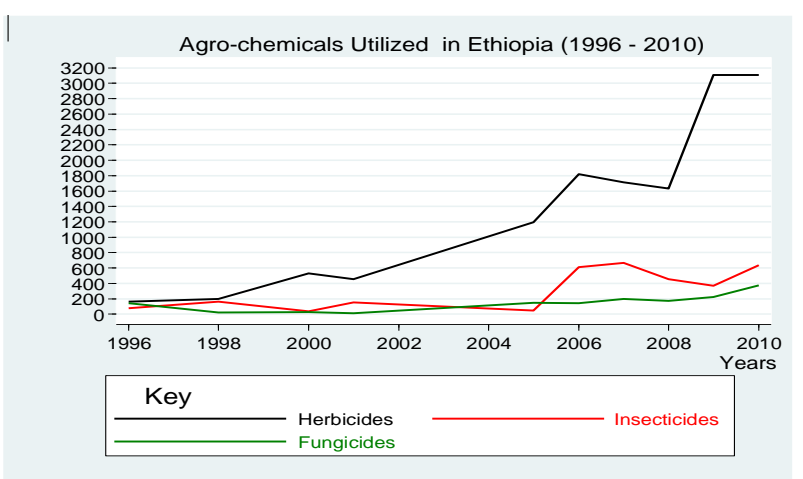

Figure 2. Type and amount of agro-chemicals utilized by smallholder farmers (Source: FAOSTAT, 2019)

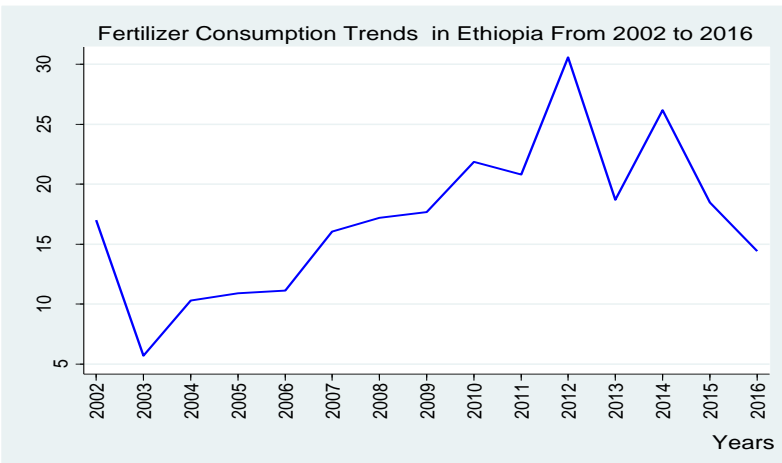

Figure 3. Fertilizer consumption from 2002 to 2016

(kilograms per hectare of arable land)
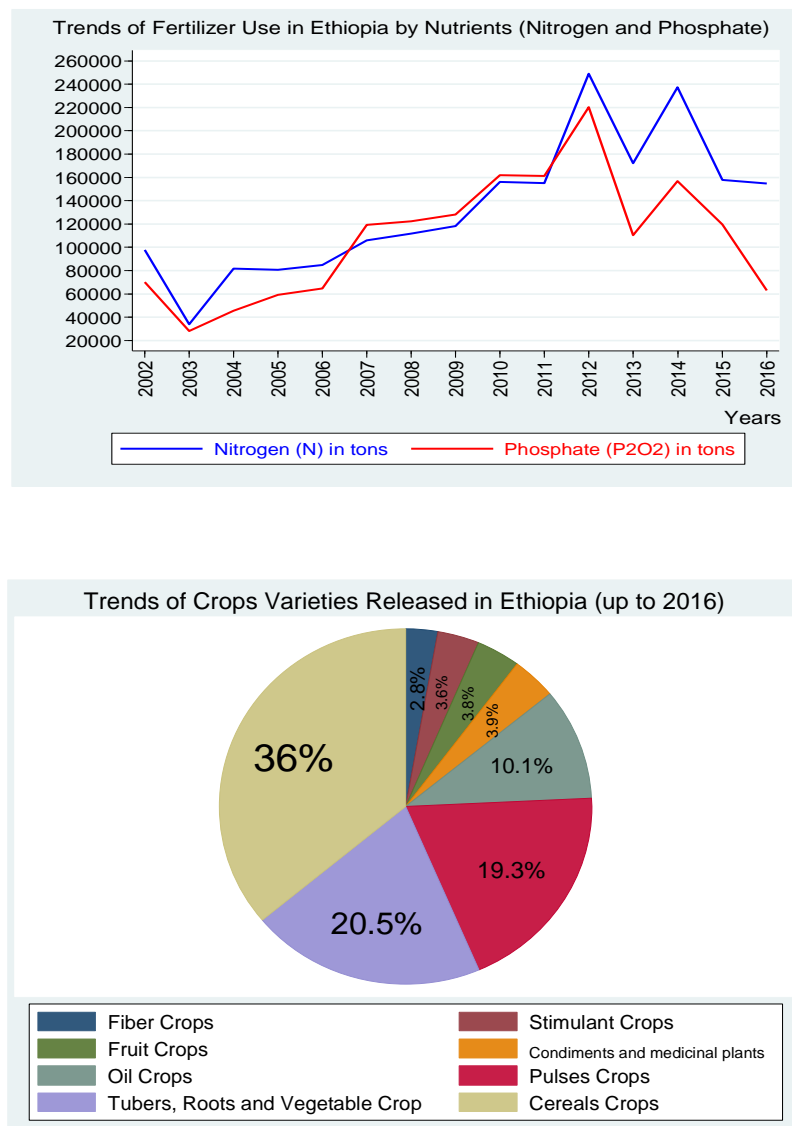

Figure 5. Trends in crops varieties released in Ethiopia (Source: MoA, 2013; MoANR, 2016)

MoANR = Ministry of Agriculture and Natural Resources

MoA = Ministry of Agriculture

\section{Result and Discussion}

Trends in the Utilization of Improved Agricultural Inputs in Ethiopia

Trends in the Use of Pesticides

As Figure 1 indicates, pesticides utilization of smallholder farmers for the agricultural purpose increased by two times from 300 tons in 1996 to 600 tons in 2001. In 2006, the consumption increased to 2600 tonnes which means four times that of 2001. Although the trend of utilizing pesticides in Ethiopia increases from 300 tons in 1996 to 4000 tons in 2010, the increments became constant for about seven years from 2010 to 2016 (FAOSTAT, 2019).

Trends in Use of Agrochemicals: Herbicides, Insecticides and Fungicides

As figure 2 showed, from 1996 to 2010 about 3000 tons of various types of herbicides were utilized by smallholder farmers in Ethiopia. These include phenoxy hormone products, triazines, amides, dinitroanilines, glyphosate, 2 4-D, and other herbicides. For instance, 2-4-D is the most important herbicide imported into the country as well as the most widely used herbicide since it has a lower price relative to other types of herbicides. Since 2-4-D kills only broadleaf weeds, weeding is required after the use of 2-4D. Therefore, other wider-ranging herbicides are increasingly being used (Tamru et al., 2017).

Moreover, about 600 tons of various insecticides were utilized in Ethiopia from 1996 to 2010. The types of insecticides applied were chlorinated hydrocarbons, organophosphates, carbamates insecticides, pyrethroids, and other insecticides. Furthermore, 400 tons of various types of fungicides such as inorganics, dithiocarbonates, benzimidazoles, triazoles, diazoles, and other fungicides were utilized from 1996 to 2010.

Trends in Chemical Fertilizer Utilization

Chemical fertilizer was first introduced to Ethiopia under the Freedom from Hunger Program of the FAO in the late 1960s. The total imports of fertilizer increased to 890,000 tons in 2012 (Rashid et al., 2013). Despite imports of fertilizer to Ethiopia increased from the 1960s to 2012, utilization of inorganic fertilizer (primarily DAP and urea) is low in the country, particularly at smallholder farmers level (IFPRI, 2013). Fertilizer consumption (kilograms per hectare of arable land) was $14.4 \mathrm{~kg} \mathrm{ha}^{-1}$ in 2016 which is below those recommended by the extension programs as well as less than the world average of 100 kilograms per hectare per year. Figure 3 indicates trends of fertilizer consumption (kilograms per hectare of arable land) increases from about five kilograms per hectare per year in 2003 to about 30 kilograms per hectare per year in 2012 . However, the increment was not based on the regular basis.

As Figure 4 shows fertilizer use trends in Ethiopia from 2002 to 2016 aggregated by nitrogen and phosphate nutrients in tons. The trends in utilizing nitrogen fertilizer nutrients increased from 97,000 tons in 2002 to 248,000 tons in 2012 then decreased to 150,000 tons in 2016. Regarding trends of using phosphate fertilizer nutrient, it increased from 70,000 tons in 2002 to 220,000 tons in 2012 and again decreased to 60,000 tons in 2016. Other fertilizer nutrients like nutrient potash $\left(\mathrm{K}_{2} \mathrm{O}\right)$ was rarely utilized in Ethiopia. For instance, only about 4000 tons of potash nutrients utilized by Ethiopian farmers from 2012 to 2016 
$(180,250,1400,2050$, and 330 tons in 2012, 2013, 2014, 2015, and 2016 respectively (FAOSTAT, 2019).

Trends in Use of Improved Seeds

A seed is the basic input in agriculture and determines the use of other inputs (Venkatesh and Pal, 2014). However, the average yield of staple food crops in Ethiopia is still low (FAOSTAT, 2013). The low yield is mainly attributed to the low use of improved inputs. Evidence shows that only $7.3 \%$ of the area under cereals was planted with improved varieties in 2010/2011 (CSA, 2011). While maize is far better than the other crops in terms of percentage of area under improved varieties (28\%), the adoption rate is still low as compared to several countries in eastern and southern Africa such as Zimbabwe (80\%), Zambia (75\%), Kenya (72\%), and 35\% in Uganda (Bernard et al., 2013). In 2011/2012, seed supply covered only $51 \%$ of stated demand for barley, $24 \%$ for wheat, $16 \%$ for rice, $30 \%$ for millet, and $60 \%$ for faba bean (MoA, 2013).

As Figure 5 shows, in Ethiopia, more than 1000 improved crop varieties were released by the national agricultural system for use together with their agronomic packages (MoANR, 2016). About 63 were released recently (i.e., in 2016). Up to 2016, among the grain crops released, cereals account for 387 (36\%), followed by tubers, roots and vegetable crops 221 (20.5\%); pulses crops 207 (19.3\%); oil crops $108(10.1 \%)$; medicinal plants 42 (3.9\%); fruits 41 (3.8\%); stimulant crops 39 (3.6\%) and fiber crops $30(2.8 \%)$ (MoANR, 2016). Figure 5 depicts trends in the type of crops and released varieties in Ethiopia up to 2016.

Trends in the Production of Major Cereals Using Improved Inputs

Improved agricultural inputs potentially help farmers to boost their productivity. Recent literature identifies a strong relationship between the use of improved agricultural inputs and crop yields and economic growth (McArthur and
McCord, 2017). Table 1 provides information on yield per hectare of major crops in Ethiopia since 1996.Yield per hectare of all crops has increased by more than two times from 1996-2017. Maize has been recorded the most significant increase since 1996 with its yield increasing from $1683 \mathrm{~kg}$ per hectare in 1996 to $3734 \mathrm{~kg}$ per hectare in 2017. The productivity of wheat has also increased from $1211 \mathrm{~kg}$ per hectare in 1996 to $2813 \mathrm{~kg}$ per hectare in 2017. Sorghum and barley recorded much slower rate of growth in productivity compared to maize and wheat.

In terms of the type of crops, Table 2 indicates that the productivity of oil crops has increased by three times from $367 \mathrm{~kg}$ per hectare in 1996 to $1075 \mathrm{~kg}$ per hectare in 2017. The productivity of cereal, pulses and spices crops also increased by more than two times from 1996-2017. The productivity of vegetables has been increased substantially. Productivity in fiber, fruits, roots, and tubers has shown much disappointing trend.

Sources of Improved Agricultural Inputs in Ethiopia

The majority of pesticides available in Ethiopia are imported mainly from China and India and distributed by the private sector. The importers typically sell their products to government enterprises and private wholesalers in major cities such as Addis Ababa, Adama, Bahir Dar and Mekelle. The latter then distribute to private retailers that sell the products to farmers in rural areas. Table 3 shows that most of the chemical fertilizer and improved seeds distribution is assured by the government through its cooperative networks. The distribution of agrochemicals, in contrast, is mostly in the hands of private distributors. The private sector plays an even larger role in the distribution of herbicides-close to 70 percent of farmers obtained the herbicides through a private channel.

Table 1. Yield per hectare of major crops (kilogram per hectare). Source: FAOSTAT (2019)

\begin{tabular}{l|cccc}
\hline \multirow{2}{*}{ Year } & \multicolumn{3}{|c}{ Name of crops } & Wheat \\
\cline { 2 - 4 } & Barley & Maize & Sorghum & 1211 \\
1996 & 1061 & 1683 & 1357 & 1292 \\
1997 & 1062 & 1738 & 1414 & 1374 \\
1998 & 1095 & 1617 & 1103 & 1115 \\
2000 & 920 & 1715 & 1248 & 1163 \\
2001 & 913 & 1620 & 1175 & 1326 \\
2002 & 1084 & 1743 & 1139 & 1435 \\
2003 & 1441 & 1875 & 1365 & 1387 \\
2004 & 1011 & 1532 & 1336 & 1469 \\
2005 & 1096 & 1613 & 1357 & 1557 \\
2006 & 1157 & 2006 & 1369 & 1520 \\
2007 & 1413 & 2640 & 1481 & 1671 \\
2008 & 1247 & 1969 & 1582 & 1624 \\
2009 & 1373 & 2137 & 1734 & 1827 \\
2010 & 1550 & 2199 & 1836 & 1838 \\
2011 & 1628 & 2540 & 2087 & 2029 \\
2012 & 1672 & 2954 & 2054 & 2110 \\
2013 & 1749 & 3059 & 2106 & 2445 \\
2014 & 1872 & 3254 & 2282 & 2543 \\
2015 & 1965 & 3421 & 2365 & 2794 \\
2016 & 2167 & 3733 & 2569 & 2675 \\
2017 & 2111 & 2525 & 2813 \\
\hline
\end{tabular}


Table 2. Yield per hectare by crops type (kilogram per hectare). Source: FAOSTAT (2019)

\begin{tabular}{|c|c|c|c|c|c|c|c|c|}
\hline \multirow{2}{*}{ Year } & \multicolumn{8}{|c|}{ Type of Crops } \\
\hline & Cereals crops & Oil Crops & Pulses Crops & Spices Crops & Roots and Tubers & Fiber Crops & Fruit Crops & Vegetables \\
\hline 1996 & 829 & 367 & 632 & 472 & 7586 & 77.6 & 28170 & 7267 \\
\hline 1997 & 910 & 377 & 550 & 493 & 7674 & 77.7 & 28333 & 7266 \\
\hline 1998 & 735 & 342 & 478 & 454 & 7801 & 77.8 & 27986 & 7268 \\
\hline 1999 & 773 & 382 & 566 & 389 & 7812 & 77.9 & 28214 & 7277 \\
\hline 2000 & 802 & 398 & 664 & 478 & 7873 & 78.3 & 28096 & 7273 \\
\hline 2001 & 789 & 354 & 592 & 667 & 7817 & 77.8 & 28158 & 7291 \\
\hline 2002 & 882 & 363 & 588 & 666 & 7866 & 80.0 & 28154 & 7298 \\
\hline 2003 & 700 & 342 & 587 & 687 & 7881 & 77.4 & 28185 & 7284 \\
\hline 2004 & 722 & 422 & 512 & 727 & 7843 & 76.9 & 28287 & 7314 \\
\hline 2005 & 973 & 522 & 769 & 709 & 7883 & 76.2 & 27850 & 7295 \\
\hline 2006 & 1034 & 479 & 889 & 632 & 7867 & 75.4 & 27044 & 7339 \\
\hline 2007 & 986 & 538 & 975 & 787 & 7683 & 74.5 & 26323 & 7282 \\
\hline 2008 & 857 & 560 & 709 & 766 & 7402 & 73.6 & 25427 & 7503 \\
\hline 2009 & 1228 & 615 & 1268 & 1280 & 7219 & 72.7 & 24916 & 8323 \\
\hline 2010 & 1261 & 585 & 1058 & 1220 & 7015 & 71.6 & 24662 & 8743 \\
\hline 2011 & 1281 & 603 & 1069 & 1158 & 7167 & 70.5 & 24399 & 9201 \\
\hline 2012 & 1379 & 700 & 1086 & 891 & 7273 & 67.3 & 24533 & 10178 \\
\hline 2013 & 1465 & 703 & 1094 & 963 & 7324 & 64.6 & 24555 & 10067 \\
\hline 2014 & 1575 & 889 & 1123 & 1032 & 7229 & 66.2 & 24261 & 10462 \\
\hline 2015 & 1720 & 1005 & 1106 & 1040 & 6191 & 67.0 & 24000 & 9969 \\
\hline 2016 & 1663 & 1075 & 1255 & 1062 & 5449 & 67.2 & 23920 & 10040 \\
\hline 2017 & 1666 & 1075 & 1231 & 1084 & 4797 & 66.6 & 23898 & 10092 \\
\hline
\end{tabular}

Table 3. Source of agro-chemicals purchased by smallholder farmers

\begin{tabular}{l|cccccc}
\hline \multicolumn{1}{c|}{ Sources } & \multirow{2}{*}{ Herbicides } & \multirow{2}{*}{ Insecticide } & \multirow{2}{*}{ Fungicides } & \multicolumn{2}{c}{ Fertilizers } & \multirow{2}{*}{ Improved seed } \\
\cline { 5 - 6 } & & & & DAP & Urea & 87.6 \\
Government & 27.0 & 31.4 & 43.3 & 83.3 & 84.8 & 6.2 \\
Private & 67.7 & 64.0 & 51.1 & 13.9 & 11.9 & 2.3 \\
Other farmers & 3.8 & 2.7 & 2.7 & 1.1 & 1.0 & 2.4 \\
Development organizations & 0.3 & 0.7 & 1.6 & 1.4 & 1.9 & 1.4 \\
Others & 1.1 & 1.2 & 1.4 & 0.3 & 0.4 & 100.0 \\
\hline Total & 100.0 & 100.0 & 100.0 & 100.0 & 100.0 & 100 \\
\hline
\end{tabular}

Source: Adapted from 2011 Agricultural Growth Program (AGP) Baseline Survey dataset cited in Tamru et al. (2017)

\section{Conclusion}

The major reasons behind the poor performance of the Ethiopian agriculture and the existing structural food insecurity and poverty in the country can be summarized to limited, irregular and unsustainable use of improved agricultural inputs. The poor input supply and distribution system as well as the limited capacity of agricultural extension workers also other challenges for agricultural growth of the country. Although there are numerous agricultural inputs disseminated from various sources to farmers, there is limited success in terms of the number of farmers reached due to poor infrastructure, weak research-extension-farmers linkage, limited and untimely supply of fertilizers and limited use of ICT applications.

Delivery services of improved agricultural inputs to smallholder farmers were influenced by numerous factors in Ethiopia. Thus, GOs, NGOs, private sectors and other institutions should work on enhancing the supply and distribution of inputs at the right time and place.

The linkage between research and extension organizations is weak. Research outputs do not reach farmers and remain shelved in research centres and higher institutions. Thus, strong integration between agricultural research, universities and extension workers are essential for research results dissemination and so that concerned bodies should work for the interlinked and interdependence of these actors.
All-weather road plays a great role for input delivery and utilization. This would also provide an excellent network among the farmers. Thus, it is recommended that the concerned bodies should improve basic infrastructural facilities for rural farmers.

\section{Acknowledgement}

We would like to express our thanks to our colleagues and friends for their constructive comments and suggestions to develop this paper review.

\section{References}

Ajah J, Nmadu JN. 2012. Small-scale maize farmers access to farm inputs in Abuja, Nigeria. Kasetsart Journal-Social Sciences, 33(3): 499-505.

Alia DY. 2017. Agricultural input intensification, productivity growth, and the transformation of African agriculture. PhD Dissertation, Agricultural Economics, 59, US. https://uknowledge.uky.edu/agecon_etds/59

Ayele S, Bosire CK. 2011. Farmers' use of improved agricultural inputs and practices: review and synthesis of research in Ethiopia. Improving Productivity and Market Success (IPMS), Ethiopia. 
Belay K, Alemu D. 2017. Agricultural research and extension linkages: Challenges and intervention options. Ethiopian Journal of Agricultural Sciences, 27(1): 55-76.

Bernard T, Abate GT, Lemma S. 2013. Agricultural cooperatives in Ethiopia: Results of the 2012 ATA (Agricultural Transformation Agency) baseline survey. International Food Policy Research Institute, Washington DC.

Chianu JN, Chianu JN, Mairura F. 2012. Mineral fertilizers in the farming systems of sub-Saharan Africa. A review. Agronomy for Sustainable Development, 32(2): 545-566.

Chirwa E, Dorward A. 2013. Agricultural input subsidies: The recent Malawi experience. Oxford University Press.

Central Statistical Agency (CSA), 2011. Report on area and production of major crops (Meher Season). Central Statistical Agency, Addis Ababa.

Delzeit R, Lewandowski I, Arslan A, Cadisch G, Erisman JW, Ewert F, Plieninger T. 2018. How the sustainable intensification of agriculture can contribute to the sustainable development goals. The need for specific socio-ecological solutions at all spatial levels. Working Paper No. 18/1.

Diagne A, Midingoyi SKG, Kinkingninhoun-Medagbe FM. 2013. Impact of NERICA adoption on rice yield: Evidence from West Africa. In: An African Green Revolution, Springer, Dordrecht.

Druilhe Z, Barreiro-Hurle J. 2012. Fertilizer subsidies in subSaharan Africa. ESA Working Paper No. 12-04. Rome, FAO.

FAOSTAT, 2013. http://faostat.fao.org, accessed Jul 22, 2014

FAOSTAT, 2019. http://faostat.fao.org, accessed January 2019

Gebrehiwot T, van der Veen A. 2014. Coping with food insecurity on a micro- scale: Evidence from Ethiopian rural households. Ecology of Food and Nutrition, 53(2): 214-240.

Gebremedhin B, Jemaneh S, Hoekstra D, Anandajayasekeram P. 2012. A guide to market-oriented extension services with special reference to Ethiopia. IPMS Project, Ethiopia, International Livestock Research Institute (ILRI), Nairobi.

Gerstenmier A. 2015. Agricultural input supply: An action plan for African agricultural transformation, Background Paper, Feeding Africa, 21-23 October 2015.

Hazell PB. 2009. The Asian Green Revolution. International Food Policy Research Institute (IFPRI) Discussion Paper 00911.

International Fertilizer Development Center (IFDC), 2015. Assessment of fertilizer consumption and use by crop in Ethiopia.

International Food Policy Research Institute (IFPRI), 2013. Why Ethiopian farmers need weather insurance. IFPRI, Washington.

Li D, Liu M, Deng G. 2010. Willingness and determinants of farmers' adoption of new rice varieties. China Agricultural Economic Review, 2(4): 456-471.

McArthur JW, McCord GC. 2017. Fertilizing growth: Agricultural inputs and their effects in economic development. Journal of Development Economics, 127: 133-152.

Mellor J.W. 2014. High rural population density Africa-What are the growth requirements and who participates? Food Policy, 48: 66-75.
Ministry of Agriculture (MoA), 2013. Data on demand and supply of improved seed of different crops. Ministry of Agriculture, Addis Ababa, Ethiopia.

Ministry of Agriculture and Natural Resources (MoANR), 2016. Plant Variety Release, Protection and Seed Quality Control Directorate, Crop Variety Register Issue No. 19, June 2016, Addis Ababa, Ethiopia.

Muktar ST, Mohamad JH, Woldemichael YM. 2014. Dimensions and Determinants of Agro-Pastoral Households' Poverty in Dembel District of Somali Regional State, Ethiopia. Journal of Poverty, Investment and Development, 3: 6-12.

Rashid S, Tefera N, Minot N, Ayele G. 2013. Fertilizer in Ethiopia: An assessment of policies, value chain, and profitability. IFPRI Discussion Paper 01304, Addis Ababa, Ethiopia.

Salami A, Kamara AB, Brixiova Z. 2010. Smallholder agriculture in East Africa: Trends, constraints and Opportunities. Working Papers Series, No 105, African Development Bank, Tunis, Tunisia.

Sheahan M, Barrett CB. 2014. Understanding the agricultural input landscape in sub Saharan Africa: Recent plot, household, and community-level evidence. Policy Research Working Paper 7014, World Bank, Washington, DC.

Sheahan M, Barrett CB. 2017. Ten striking facts about agricultural input use in Sub-Saharan Africa. Food Policy, 67: $12-25$.

Sheahan M, Black R, Jayne TS. 2013. Are Kenyan farmers' underutilizing fertilizer? Implications for input intensification strategies and research. Food Policy, 41: 39-52.

Smaling E, Toure M, Ridder N, Sanginga N, Breman H. 2006. Fertilizer use and the environment in Africa: friend or foes? Background paper prepared for the African Fertilizer Summit, June 9-15, 2006, Abuja, Nigeria.

Tamru S, Minten B, Alemu D, Bachewe F. 2017. The rapid expansion of herbicide uses in smallholder agriculture in Ethiopia: Patterns, drivers, and implications. The European Journal of Development Research, 29(3): 628-647.

Venkatesh P, Nithyashree ML. 2014. Institutional Changes in Delivery of Agricultural Inputs and Services to Farm Households in India. Agricultural Economics Research Review, 27: 85-92.

Venkatesh P, Pal S. 2014. Impact of Plant Variety Protection on Indian Seed Industry. Agricultural Economics Research Review, 27(1): 91-102.

Wiggins S, Brooks J. 2010. The Use of Input Subsidies in Developing Countries. The Organization for Economic Cooperation and Development, Presented to the Working Party on Agricultural Policy and Markets, Global Forum on Agriculture, 15-17 November 2010.

World Bank, 2013. Unlocking Africa's Agricultural Potential. An Action Agenda for Transformation, Washington, DC.

Yihun YM, Haile AM, Schultz B, Erkossa T. 2013. Crop water productivity of irrigated teff in a water stressed region. Water Resource Management, 27(8): 3115-3125 